\title{
Are culturally vibrant communities healthier? Relationships between performing arts activity and health outcomes in the 500 largest US cities
}

\author{
J. Matt McCrary ${ }^{1,2}$ \\ Michael Großbach ${ }^{1}$ \\ Eckart Altenmüller ${ }^{1}$
}

${ }^{1}$ Institute of Music Physiology and Musicians' Medicine, Hannover University of Music Drama and Media; Hannover, Germany

${ }^{2}$ Prince of Wales Clinical School, Faculty of Medicine, UNSW Sydney; Sydney, Australia

Corresponding Author:

J. Matt McCrary

Institute for Music Physiology and Musicians' Medicine

Hannover University for Music, Drama and Media

Neues Haus 1

30175 Hannover

Germany

j.matt.mccrary@gmail.com

KEYWORDS: Public Health; Music; Dance; Theatre; Epidemiology 
medRxiv preprint doi: https://doi.org/10.1101/2021.07.26.21261123; this version posted July 28, 2021. The copyright holder for this preprint (which was not certified by peer review) is the author/funder, who has granted medRxiv a license to display the preprint in perpetuity.

It is made available under a CC-BY-ND 4.0 International license .

\section{Abstract}

2 Aims: Recent reviews have demonstrated broad links between performing arts participation (e.g. music-making; dancing; acting) and receptive engagement (e.g. listening to music; attending a

4 dance/theatre performance) and improved health, including reduced disease and mortality risk.

5 However, no investigations to date have interrogated the links between community-level

6 performing arts activity (i.e. participation + receptive engagement) and health outcomes - i.e. do

7 the performing arts help create healthy communities? This study aims to address this question by

8 examining links between performing arts activity and health outcomes across 500 cities in the

9 United States.

Methods: Secondary analysis of demographic, health outcome, performing arts activity

11 (estimated by annual performing arts revenue), and preventive/unhealthy behaviour data for 500

12 large cities in the United States - data extracted from the US Centers for Disease Control 500

13 Cities Project, Dun \& Bradstreet Hoovers Database, and US Census. Links between performing

14 arts activity and 12 health/disease outcomes were evaluated using a series of hierarchical beta

15 regression models which progressively controlled for demographic variables and

16 preventive/unhealthy behaviour prevalence.

17 Results: The 500 analysed US cities comprise $33.4 \%$ of the total US population and 84,010

18 performing arts businesses (total annual revenue $\$ 27.84$ billion). No significant associations

19 were found between performing arts activity and nine of twelve health outcomes in fully adjusted

20 models ( $\mathrm{p} \geq .17$ ). Statistically significant relationships $(\mathrm{p}<.01)$ between increased performing arts

21 activity and increased prevalence of chronic kidney disease, coronary heart disease, and stroke

22 were determined to be clinically equivocal. 
23 Conclusions: This study contributes to a growing body of conflicting epidemiologic evidence

24 regarding the impact of the performing arts on health/disease and mortality outcomes, evaluated

25 using a range of disparate methodologies. A consensus, psychometrically rigorous approach is

26 required to address this prevailing uncertainty in future epidemiologic studies examining effects

27 of performing arts activities both within and across countries and communities.

28

29

30

31

32

33

34

35

36

37

38

39

40

41 
medRxiv preprint doi: https://doi.org/10.1101/2021.07.26.21261123; this version posted July 28, 2021. The copyright holder for this preprint (which was not certified by peer review) is the author/funder, who has granted medRxiv a license to display the preprint in perpetuity.

It is made available under a CC-BY-ND 4.0 International license .

42

43

44

45

46

47

\section{Introduction}

Recent systematic and scoping reviews have demonstrated broad links between performing arts participation (e.g. music-making; dancing; acting) and receptive engagement (e.g. listening to music; attending a dance or theatre performance) and improved health and wellbeing $(1,2)$. Included amongst these broad health benefits are suggestive links between the performing arts and a reduced risk of early mortality and non-communicable diseases including cancer, dementia and cardiovascular disease (3-7). However, no investigations to date have interrogated the links between community-level performing arts activity (i.e. participation + receptive engagement) and health outcomes - in other words, do the performing arts help create healthy communities?

In addition to being directly health-promoting activities, the performing arts are also substantial contributors to culture in communities in the United States, with culture also independently noted to substantially impact health (8). The performing arts (i.e. music, dance, theatre) are the most popular artistic modalities in the United States - $43 \%$ of adults attend performing arts events at least once annually; 74\% engage with the performing arts using electronic media (e.g. television; online); and $40 \%$ participate in the performing arts (i.e. play an instrument, sing, dance, act) at least once every year (9). This study aims to provide insights into the impact of the performing arts on community health by examining links between performing arts activity and health outcomes across 500 cities in the United States.

\section{Methods}

Study aims were addressed through secondary analyses of data obtained from the US Centers for Disease Control and Prevention 500 Cities Project (10), Dun \& Bradstreet Hoovers Database (11), and the US Census Bureau (12). 
medRxiv preprint doi: https://doi.org/10.1101/2021.07.26.21261123; this version posted July 28, 2021. The copyright holder for this preprint (which was not certified by peer review) is the author/funder, who has granted medRxiv a license to display the preprint in perpetuity.

It is made available under a CC-BY-ND 4.0 International license .

US Centers for Disease Control and Prevention 500 Cities Project (10) - Health Outcomes;

Unhealthy \& Preventive Behaviours

67

The 500 Cities Project uses small area estimation methods (13) to approximate the prevalence of

6813 health outcomes, 9 preventive behaviours, and 5 unhealthy behaviours in the 497 largest US

cities (as per 2010 US census). Additionally, to ensure representation from each US state, data

from the largest cities in Vermont, West Virginia and Wyoming are included. The 2019 release

of 500 Cities Project data was used in the present study.

Included health outcomes are: arthritis; asthma; cancer; chronic kidney disease; chronic

high cholesterol; poor mental health; poor physical health; tooth loss (all teeth); and stroke.

(mammography); cervical cancer screening (Papanicolanou smear); cholesterol screening;

79 colorectal cancer screening (colonoscopy, sigmoidoscopy, faecal occult blood test); core set of

81 medication adherence. All data are reported as an age-adjusted \% prevalence of the respective

82 health outcome or behaviour for each of the 500 included cities. Full details of the 500 Cities

83 Project can be found in (10).

85 Dun \& Bradstreet Hoovers (11)-Performing Arts Activity

86 Performing arts activity was estimated for each of the 500 cities included in the 500 Cities

87 Project by extracting annual revenue (2019) data for performing arts-related for- and non-profit 
medRxiv preprint doi: https://doi.org/10.1101/2021.07.26.21261123; this version posted July 28, 2021. The copyright holder for this preprint (which was not certified by peer review) is the author/funder, who has granted medRxiv a license to display the preprint in perpetuity.

It is made available under a CC-BY-ND 4.0 International license .

entities from the Dun \& Bradstreet Hoovers database. Hoovers is the world's largest commercial financial database including over 170 million businesses, and has been previously used to estimate cultural activity in US cities and analyse relationships between cultural activity and health outcomes (14). Performing arts-related entities were identified by eight-digit Standard Industrial Classification (SIC) codes (15), with 78 codes related to performing arts participation and/or receptive engagement selected for inclusion (Supplementary Table 1). All included SIC codes are related to participation and/or receptive engagement with live performing arts. SIC codes related to recorded performing arts were explicitly excluded given more tenuous links between revenue and performing arts participation/receptive engagement.

\section{US Census Bureau (12) - Demographic covariates}

Population, median per capita income and racial (\% White, African-American, Hispanic) data were extracted from the most recent US Census (2010) for each of the 500 cities included in the 500 Cities Project. Demographic data were extracted to serve as covariates given the demonstrated impact of economic and racial disparities on health outcomes $(16,17)$.

\section{Statistical analyses}

Relationships between performing arts activity and each health outcome were analysed using a series of hierarchical beta regression models. Beta regression has been shown to be ideal for effectively modelling proportion outcomes (i.e. the 13 included health outcomes) which are limited to the interval $[0,1](18)$. Hierarchical modelling enabled consideration of established social and economic relationships between cities contained within the same metropolitan area;

for example, hierarchical models could appropriately treat Santa Monica, Los Angeles (city), and Long Beach as related cities with the Los Angeles metropolitan area, rather than completely independent entities (19). Hierarchical models included two levels: Level $1=$ metropolitan areas 
medRxiv preprint doi: https://doi.org/10.1101/2021.07.26.21261123; this version posted July 28, 2021. The copyright holder for this preprint (which was not certified by peer review) is the author/funder, who has granted medRxiv a license to display the preprint in perpetuity.

It is made available under a CC-BY-ND 4.0 International license .

111 including at least one of the analysed 500 cities; Level $2=$ the individual 500 cities, coded and

112 stratified by metropolitan area. Metropolitan areas were defined using Combined Statistical Area

113 designations assigned by the US Office of Management and Budget in reflection of social and

114 economic links between cities $(20,21)$.

115 Four hierarchical beta regression models were created using the PROC GLIMMIX procedure in

116 SAS v9.4 (SAS Institute Inc., Cary, NC, USA) to analyse the relations between performing arts

117 activity and each of the 13 health outcomes across the 500 included cities:

Model 1 - completely unadjusted

Model 2 - adjusted for demographic covariates (median annual per capita income; population size; \% White; \% African-American; \% Hispanic)

All models exceed recommended ratios of observation to predictor variables; additionally, a priori designation of covariates has been shown to minimize potential risks of overfitting (22). Variance Inflation Factors for predictor variables (i.e. performing arts activity) were checked to ensure that potentially problematic levels of multicollinearity (Variance Inflation Factor > 10)

127 were not present (23). Using the logit link, odds ratios were derived from parameter estimates of 128 each model (18); odds ratios are multipliers describing the impact of a $\$ 1$ billion increase in 129 performing arts revenue on the \% prevalence of each health outcome. Analyses of cancer 130 prevalence were excluded due to particularly tight clustering of cancer prevalence data which 131 precluded accurate modelling. Missing cervical cancer screening data from 47 cities were multiply imputed (10 imputations) using the PROC MI procedure (SAS v9.4); Model 4 
medRxiv preprint doi: https://doi.org/10.1101/2021.07.26.21261123; this version posted July 28, 2021. The copyright holder for this preprint (which was not certified by peer review) is the author/funder, who has granted medRxiv a license to display the preprint in perpetuity.

It is made available under a CC-BY-ND 4.0 International license.

MIANALYZE procedure (SAS v9.4). Data for all other investigated variables were complete.

\begin{tabular}{|c|c|c|c|}
\hline & Median & Minimum & Maximum \\
\hline Annual performing arts revenue (\$ - millions) & 7.56 & 0.29 & 4186.22 \\
\hline Population & 106,106 & 42,417 & $8,175,133$ \\
\hline Median annual per capita income (\$) & 29,031 & 14,509 & 90,042 \\
\hline \multicolumn{4}{|l|}{ Racial Demographics (\%) } \\
\hline White & 72.2 & 12.3 & 96.8 \\
\hline African-American & 9.7 & 0.0 & 84.9 \\
\hline Hispanic & 16.4 & 1.0 & 96.8 \\
\hline \multicolumn{4}{|l|}{ Health Outcomes (\% prevalence) } \\
\hline Arthritis & 22.0 & 13.3 & 33.9 \\
\hline Asthma & 9.4 & 6.7 & 14.2 \\
\hline Chronic kidney disease & 3.1 & 2.1 & 4.8 \\
\hline Chronic obstructive pulmonary disease & 6.1 & 3.1 & 11.3 \\
\hline Coronary heart disease & 5.7 & 3.5 & 8.8 \\
\hline Diabetes & 10.3 & 5.6 & 20.3 \\
\hline High blood pressure & 30.0 & 20.7 & 47.3 \\
\hline High cholesterol & 29.5 & 24.1 & 34.1 \\
\hline Poor mental health & 13.6 & 8.3 & 19.6 \\
\hline Poor physical health & 12.7 & 7.0 & 20.5 \\
\hline Teeth lost (all) & 14.5 & 5.1 & 31.8 \\
\hline Stroke & 3.1 & 1.8 & 6.1 \\
\hline \multicolumn{4}{|l|}{ Unhealthy Behaviours (\% prevalence) } \\
\hline Binge drinking & 17.7 & 6.2 & 25.4 \\
\hline Current smoker & 17.2 & 7.9 & 29.6 \\
\hline Insufficient sleep & 35.4 & 24.5 & 50.1 \\
\hline Physical inactivity & 26.2 & 12.9 & 45.4 \\
\hline Obesity & 30.5 & 15.3 & 49.1 \\
\hline \multicolumn{4}{|l|}{ Preventive Behaviours (\% prevalence) } \\
\hline Annual dental & 63.4 & 41.8 & 81.5 \\
\hline Annual medical & 67.9 & 54.2 & 81.3 \\
\hline Breast cancer screening & 74.9 & 60.0 & 83.5 \\
\hline Cervical cancer screening & 78.6 & 67.7 & 85.9 \\
\hline Cholesterol screening & 79.8 & 70.2 & 85.2 \\
\hline Colon cancer screening & 64.6 & 43.2 & 77.7 \\
\hline Health insurance & 15.1 & 4.8 & 43.9 \\
\hline High blood pressure medication adherence & 57.1 & 46.6 & 69.7 \\
\hline Preventive services - older men & 34.0 & 19.4 & 53.3 \\
\hline Preventive services - older women & 32.1 & 17.5 & 46.6 \\
\hline
\end{tabular}

Table 1. Descriptive demographic, health outcome and behavioural data for the 500 analysed 136 cities. 
medRxiv preprint doi: https://doi.org/10.1101/2021.07.26.21261123; this version posted July 28, 2021. The copyright holder for this preprint (which was not certified by peer review) is the author/funder, who has granted medRxiv a license to display the preprint in perpetuity.

It is made available under a CC-BY-ND 4.0 International license .

\section{Results}

139 The 500 analysed US cities comprise $33.4 \%$ of the total U.S. population (103,020,808 people)

140 and 84,010 performing arts businesses with a total annual revenue of $\$ 27.84$ billion. Of this total

141 performing arts revenue, $\$ 10.42$ billion went to performing artists, $\$ 11.84$ billion went to

142 performing arts production/support services, $\$ 3.30$ billion went to performing arts venues, and

$143 \$ 2.27$ billion went to performing arts education. Median, minimum and maximum values for

144 demographic and health and behavioural outcomes across the 500 analysed cities are detailed in

145 Table 1.

147 Fully adjusted regression models (Model 4) demonstrate statistically significant associations

148 between increased performing arts activity and increased prevalence of chronic kidney disease,

149 coronary heart disease, and stroke ( $\mathrm{p}<.01$; Table 2$)$. Odds ratios indicate that a $\$ 1$ billion increase

150 in performing arts revenue is linked to increases in chronic kidney disease, coronary heart

151 disease, and stroke by factors of 1.06, 1.13, and 1.11, respectively (Figure 1). For a hypothetical

152 city of median population, performing arts revenue and incidence of health outcomes, Model 4

153 demonstrates that a $100 \%$ increase in performing arts revenue would be associated with an

154 additional 2, 6, and 3 cases of chronic kidney disease, coronary heart disease, and stroke,

155 respectively. No other significant links between performing arts activity and health outcomes

156 were found in fully adjusted models (Model 4; $\mathrm{p} \geq .17$ ). 
Model 1

Model 2

Model 3

Model 4

\begin{tabular}{|c|c|c|c|c|c|c|c|c|c|c|c|c|}
\hline & \multicolumn{3}{|c|}{ Model 1} & \multicolumn{3}{|c|}{ Model 2} & \multicolumn{3}{|c|}{ Model 3} & \multicolumn{3}{|c|}{ Model 4} \\
\hline Outcome & $\begin{array}{c}\text { Parameter } \\
\text { estimate }\end{array}$ & $S E$ & $p$ & $\begin{array}{c}\text { Parameter } \\
\text { estimate }\end{array}$ & $S E$ & $p$ & $\begin{array}{c}\text { Parameter } \\
\text { estimate }\end{array}$ & $S E$ & $p$ & $\begin{array}{c}\text { Parameter } \\
\text { estimate }\end{array}$ & $S E$ & $p$ \\
\hline Arthritis & -0.045 & 0.039 & 0.25 & 0.062 & 0.059 & 0.29 & 0.011 & 0.039 & 0.78 & 0.009 & 0.037 & 0.81 \\
\hline Asthma & 0.008 & 0.026 & 0.77 & 0.065 & 0.053 & 0.22 & 0.034 & 0.043 & 0.43 & -0.018 & 0.037 & 0.53 \\
\hline Chronic kidney disease & 0.047 & 0.027 & 0.09 & $0.103 * *$ & 0.035 & $<0.01$ & $0.061 *$ & 0.027 & 0.02 & $0.061 * *$ & 0.023 & $<0.01$ \\
\hline $\begin{array}{l}\text { Chronic obstructive } \\
\text { pulmonary disease }\end{array}$ & -0.00001 & 0.050 & 0.99 & $0.225 * *$ & 0.081 & $<0.01$ & 0.063 & 0.046 & 0.17 & 0.059 & 0.042 & 0.17 \\
\hline Coronary heart disease & 0.025 & 0.034 & 0.47 & $0.207 * * *$ & 0.052 & $<0.001$ & $0.115^{* * *}$ & 0.024 & $<0.001$ & $0.120 * * *$ & 0.023 & $<0.001$ \\
\hline Diabetes & 0.077 & 0.044 & 0.08 & 0.057 & 0.063 & 0.37 & 0.001 & 0.036 & 0.98 & 0.036 & 0.033 & 0.28 \\
\hline High blood pressure & 0.021 & 0.042 & 0.62 & -0.029 & 0.061 & 0.63 & -0.069 & 0.039 & 0.08 & -0.012 & 0.035 & 0.73 \\
\hline High cholesterol & 0.009 & 0.018 & 0.60 & 0.006 & 0.041 & 0.88 & -0.017 & 0.035 & 0.62 & 0.022 & 0.032 & 0.51 \\
\hline Poor mental health & -0.001 & 0.036 & 0.97 & $0.169 *$ & 0.055 & 0.02 & $0.076^{*}$ & 0.035 & 0.03 & 0.041 & 0.031 & 0.19 \\
\hline Poor physical health & 0.022 & 0.042 & 0.60 & $0.188 * *$ & 0.059 & $<0.01$ & $0.081 *$ & 0.034 & 0.02 & 0.043 & 0.029 & 0.14 \\
\hline Teeth lost (all) & 0.071 & 0.067 & 0.29 & $0.376 * * *$ & 0.113 & $<0.001$ & $0.177^{*}$ & 0.078 & 0.02 & 0.041 & 0.063 & 0.52 \\
\hline Stroke & 0.064 & 0.037 & 0.09 & $0.204 * * *$ & 0.045 & $<0.001$ & $0.122 * * *$ & 0.030 & $<0.001$ & $0.102 * * *$ & 0.025 & $<0.001$ \\
\hline
\end{tabular}

160

161 Table 2. Hierarchical beta regression results describing the relationships between performing arts activity and all health outcomes $*$ -

$162 \mathrm{p}<.05: * *-\mathrm{p}<.01 ; \mathrm{p}<.001$. Model 1: Unadjusted. Model 2: Adjusted for population size, median annual per capita income, and racial

163 demographics (\% White; \% African-American; \% Hispanic). Model 3: Adjusted for all in Model $2+$ prevalence of unhealthy

164 behaviours. Model 4: Adjusted for all in Model 3 + prevalence of preventive behaviours. 
medRxiv preprint doi: https://doi.org/10.1101/2021.07.26.21261123; this version posted July 28, 2021. The copyright holder for this preprint (which was not certified by peer review) is the author/funder, who has granted medRxiv a license to display the preprint in perpetuity.

It is made available under a CC-BY-ND 4.0 International license .

\section{Discussion}

This secondary analysis of performing arts activity and health outcome data across 500 US cities representing $1 / 3$ of the total US population revealed minimal links between community-level performing arts activity and health outcomes. Fully adjusted models only revealed statistically significant relationships between performing arts activity and an increased incidence of three of

171 twelve investigated health outcomes: chronic kidney disease, coronary heart disease, and stroke

172 incidence. However, the public health implications of these statistically significant links are

173 equivocal - models indicate that considerable $100 \%$ increases in performing arts revenue would

174 be linked to only single digit increases in disease incidence in most analysed cities. Such small

175 but statistically significant associations in observational epidemiologic research have been shown 176 to be most likely the result of uncontrolled bias and thus unlikely to be credible (24-26). Further,

177 performing arts participation has been shown to positively impact chronic kidney disease,

178 coronary heart disease and stroke risk factors (e.g. body composition; inflammation) in prior

179 studies (1); no links between performing arts activity and increased incidence or risk factors for

180 these diseases have been reported $(1,2)$. Accordingly, the results of this analysis are judged to 181 illustrate an absence of clinically significant associations between performing arts activity and 182 health outcomes - the remainder of the discussion has been written on this basis.

183 Given the broad benefits of performing arts participation and receptive engagement related to a 184 range of health outcomes $(1,2)$, the absence of links between community-level performing arts 185 activity and health outcomes in the present study was unexpected. However, null results of the 186 present study are far from the exception in epidemiologic studies investigating performing arts 187 impact. Only one of three studies found a positive effect of performing arts activity on all-cause mortality $(5,27,28)$, while two of three studies have demonstrated protective effects of 
medRxiv preprint doi: https://doi.org/10.1101/2021.07.26.21261123; this version posted July 28, 2021. The copyright holder for this preprint (which was not certified by peer review) is the author/funder, who has granted medRxiv a license to display the preprint in perpetuity.

It is made available under a CC-BY-ND 4.0 International license.

performing arts activity on dementia incidence $(3,7,29)$. Methods of evaluating performing arts participation and receptive engagement vary across this and prior epidemiologic studies, with a notable dearth of validated and/or psychometrically tested approaches. Taken together, variation in the content and psychometric rigour of evaluation methods seems likely to be at least partially responsible for the present prevalence of mixed results.

In the present study, use of annual performing arts revenue to estimate performing arts activity is a notably indirect assessment approach and a key limitation. The authors hypothesized that the health impact of the performing arts would be robust enough to tolerate such indirect estimation methods, particularly given the availability of a wide array of behavioural and demographic covariates which would theoretically permit the detection of smaller effects. However, results indicate that the effects of performing arts activity may be smaller and/or more specific than predicted. Additionally, associations between performing arts revenue and participation/receptive engagement may be weaker than prior research (14) suggests. And alternately, performing arts activity may simply have no effect on broad health/disease outcomes. Further epidemiologic research using a consensus, psychometrically tested approach to evaluating performing arts activity is required to more confidently and precisely quantify performing arts effects.

Notably, studies which more directly assessed performing arts activity - e.g. questionnaires regarding the type and/or frequency of performing arts activities - have also returned conflicting null and positive results $(3,5,7,27-29)$. This suggests that direct assessment methods are not inherently the solution. However, one prior study interrogating links between dancing and cardiovascular disease mortality provides guidance regarding an approach that could be expanded to evaluate performing arts more broadly (6). This study used a validated intervieweradministered questionnaire to quantify the frequency, duration and physical intensity of dancing, 
medRxiv preprint doi: https://doi.org/10.1101/2021.07.26.21261123; this version posted July 28, 2021. The copyright holder for this preprint (which was not certified by peer review) is the author/funder, who has granted medRxiv a license to display the preprint in perpetuity.

It is made available under a CC-BY-ND 4.0 International license .

212 finding that moderate, but not light, intensity dancing was linked to reduced cardiovascular

213 disease mortality.

214 While physical intensity is not relevant to many forms of performing arts participation and

215 receptive engagement, direct assessment of the physiologic response to performing arts activity

216 appears likely to facilitate better evaluations of performing arts' impact on health outcomes.

217 Physiologic responses to performing arts have been shown to be highly variable, even within the

218 same type of performing arts participation or receptive engagement - in a particularly clear

219 example, performing or listening to the same piece of music can elicit a significant physiologic

220 response in one individual but no response in another, both on average and during emotional

221 'peaks' in the music (1, 30-35). Evidence from other domains, in particular physical activity, has

222 demonstrated clear links between the short-term physiologic responses to activities and their

223 long-term impact on disease and mortality $(36,37)$. Similar links between short-term physiologic

224 responses to performing arts activities and long-term health outcomes seem likely, underscoring

225 the prospective importance of evaluating these physiologic responses in future epidemiologic

226 research.

\section{Conclusions}

228 This study contributes to a growing body of conflicting epidemiologic evidence regarding the

229 health impacts of performing arts activity, revealing no relationships between community-level

230 performing arts activity and health/disease outcome across 500 cities in the US. However,

231 considering the context, results should be interpreted as an impetus to refine and consolidate

232 presently disparate evaluation methods, rather than as conclusive insights regarding the impact of

233 performing arts activity on community-level health. A consensus, psychometrically rigorous 
medRxiv preprint doi: https://doi.org/10.1101/2021.07.26.21261123; this version posted July 28, 2021. The copyright holder for this preprint (which was not certified by peer review) is the author/funder, who has granted medRxiv a license to display the preprint in perpetuity.

It is made available under a CC-BY-ND 4.0 International license .

method of evaluating performing arts participation and receptive engagement is required to address this prevailing uncertainty in future epidemiologic studies.

\section{Funding}

The author(s) disclosed receipt of the following financial support for the research, authorship, and/or publication of this article: This work was supported by a Postdoctoral Fellowship from the Alexander von Humboldt Foundation.

\section{Conflicts of Interest}

The authors have no conflicts of interest to declare.

\section{References}

1. McCrary J, Redding E, Altenmüller E. Performing arts as a health resource? An umbrella review of the health impacts of music and dance participation. PLOS ONE. 2021;16(6):e0252956.

2. Fancourt D, Finn S. What is the evidence on the role of the arts in improving health and wellbeing? A scoping review. 2020.

3. Verghese J, Lipton RB, Katz MJ, Hall CB, Derby CA, Kuslansky G, et al. Leisure activities and the risk of dementia in the elderly. New England Journal of Medicine. 2003;348(25):2508-16.

4. Bygren LO, Johansson S-E, Konlaan BB, Grjibovski AM, Wilkinson AV, Sjöström M. Attending cultural events and cancer mortality: A Swedish cohort study. Arts \& Health. 2009;1(1):64-73.

5. Bygren LO, Konlaan BB, Johansson S-E. Attendance at cultural events, reading books or periodicals, and making music or singing in a choir as determinants for survival: Swedish interview survey of living conditions. BMJ. 1996;313(7072):1577-80.

6. Merom D, Ding D, Stamatakis E. Dancing participation and cardiovascular disease mortality: a pooled analysis of 11 population-based British cohorts. American journal of preventive medicine. 2016;50(6):756-60.

7. Balbag MA, Pedersen NL, Gatz M. Playing a musical instrument as a protective factor against dementia and cognitive impairment: A population-based twin study. International Journal of Alzheimer's Disease. 2014;2014.

8. Napier AD, Ancarno C, Butler B, Calabrese J, Chater A, Chatterjee H, et al. Culture and health. The Lancet. 2014;384(9954):1607-39.

9. National Endowment for the Arts. U.S. Patterns of Arts Participation: A full report from the 2017 Survey of Public Participation in the Arts. 2017.

10. Centers for Disease Control and Prevention - National Center for Chronic Disease Prevention and Health Promotion - Division of Population Health. 500 Cities Project Data [online]. https://www.cdc.gov/places/about/500-cities-2016-2019/index.html2019. 
medRxiv preprint doi: https://doi.org/10.1101/2021.07.26.21261123; this version posted July 28, 2021. The copyright holder for this preprint (which was not certified by peer review) is the author/funder, who has granted medRxiv a license to display the preprint in perpetuity. It is made available under a CC-BY-ND 4.0 International license .

11. Dun \& Bradstreet. Hoovers. www.dnb.com2019.

12. US Census Bureau. Census. www.census.gov2010.

13. Wang Y, Holt JB, Zhang X, Lu H, Shah SN, Dooley DP, et al. Comparison of methods for estimating prevalence of chronic diseases and health behaviors for small geographic areas: Boston validation study, 2013. Preventing chronic disease. 2017;14:E99.

14. American Association of Retired People Public Policy Institute. AARP Livability Index. 2018.

15. Dun \& Bradstreet. Firmographic code tables - SIC 8-Digit Code. https://www.dnb.com/utilitypages/dnb-demographic-firmographic-code-tables.html2019.

16. Kaplan GA, Pamuk ER, Lynch JW, Cohen RD, Balfour JL. Inequality in income and mortality in the United States: analysis of mortality and potential pathways. Bmj. 1996;312(7037):999-1003.

17. National Center for Health Statistics. Health, United States, 2015: With special feature on racial and ethnic health disparities. 2016.

18. Ferrari S, Cribari-Neto F. Beta regression for modelling rates and proportions. Journal of applied statistics. 2004;31(7):799-815.

19. Clark JS, Gelfand AE. Hierarchical modelling for the environmental sciences: statistical methods and applications: OUP Oxford; 2006.

20. US Office of Management and Budget. Revised delineations of metropolitan statistical areas, micropolitan statistical areas, and combined statistical areas, and guidance on uses of the delineations in these areas. https://www.whitehouse.gov/wp-content/uploads/2020/03/Bulletin-20-01.pdf; 2020.

21. US Census Bureau. Delineation Files. https://www.census.gov/geographies/reference-files/timeseries/demo/metro-micro/delineation-files.html2020.

22. Babyak MA. What you see may not be what you get: a brief, nontechnical introduction to overfitting in regression-type models. Psychosomatic medicine. 2004;66(3):411-21.

23. Hair JF. Multivariate data analysis. 2009.

24. Grimes DA, Schulz KF. False alarms and pseudo-epidemics: the limitations of observational epidemiology. Obstetrics \& Gynecology. 2012;120(4):920-7.

25. Ioannidis JP. Why most discovered true associations are inflated. Epidemiology. 2008:640-8.

26. Young SS, Karr A. Deming, data and observational studies: a process out of control and needing fixing. Significance. 2011;8(3):116-20.

27. Konlaan BB, Bygren LO, Johansson S-E. Visiting the cinema, concerts, museums or art exhibitions as determinant of survival: a Swedish fourteen-year cohort follow-up. Scandinavian Journal of Public Health. 2000;28(3):174-8.

28. Løkken BI, Rangul V, Merom D, Ekholm O, Krokstad S, Sund ER. Are Playing Instruments, Singing or Participating in Theatre Good for Population Health? Associations with Self-Rated Health and AllCause Mortality in the HUNT3 Study (2006-2008), Norway. Music and Public Health: Springer; 2018. p. 33-54.

29. Hughes TF, Chang $\mathrm{C}-\mathrm{CH}$, Vander Bilt J, Ganguli M. Engagement in reading and hobbies and risk of incident dementia: the MoVIES project. American Journal of Alzheimer's Disease \& Other Dementias ${ }^{\circledR}$. 2010;25(5):432-8.

30. Salimpoor VN, Benovoy M, Longo G, Cooperstock JR, Zatorre RJ. The rewarding aspects of music listening are related to degree of emotional arousal. PloS one. 2009;4(10):e7487.

31. Lynar E, Cvejic E, Schubert E, Vollmer-Conna U. The joy of heartfelt music: An examination of emotional and physiological responses. International Journal of Psychophysiology. 2017;120:118-25.

32. Grewe O, Nagel F, Kopiez R, Altenmüller E. Emotions over time: synchronicity and development of subjective, physiological, and facial affective reactions to music. Emotion. 2007;7(4):774.

33. Chapin H, Jantzen K, Kelso JS, Steinberg F, Large E. Dynamic emotional and neural responses to music depend on performance expression and listener experience. PloS one. 2010;5(12):e13812. 
medRxiv preprint doi: https://doi.org/10.1101/2021.07.26.21261123; this version posted July 28, 2021. The copyright holder for this preprint (which was not certified by peer review) is the author/funder, who has granted medRxiv a license to display the preprint in perpetuity.

It is made available under a CC-BY-ND 4.0 International license .

316 34. Nakahara H, Furuya S, Obata S, Masuko T, Kinoshita H. Emotion-related changes in heart rate 317 and its variability during performance and perception of music. Annals of the New York Academy of 318 Sciences. 2009;1169(1):359-62.

319 35. Grewe O, Nagel F, Kopiez R, Altenmüüller E. Listening to music as a re-creative process:

320 Physiological, psychological, and psychoacoustical correlates of chills and strong emotions. Music

321 Perception. 2007;24(3):297-314.

322 36. Barisic A, Leatherdale ST, Kreiger N. Importance of frequency, intensity, time and type (FITT) in 323 physical activity assessment for epidemiological research. Canadian Journal of Public Health.

324 2011;102(3):174-5.

325 37. Rhodes RE, Janssen I, Bredin SS, Warburton DE, Bauman A. Physical activity: Health impact, 326 prevalence, correlates and interventions. Psychology \& Health. 2017;32(8):942-75. 

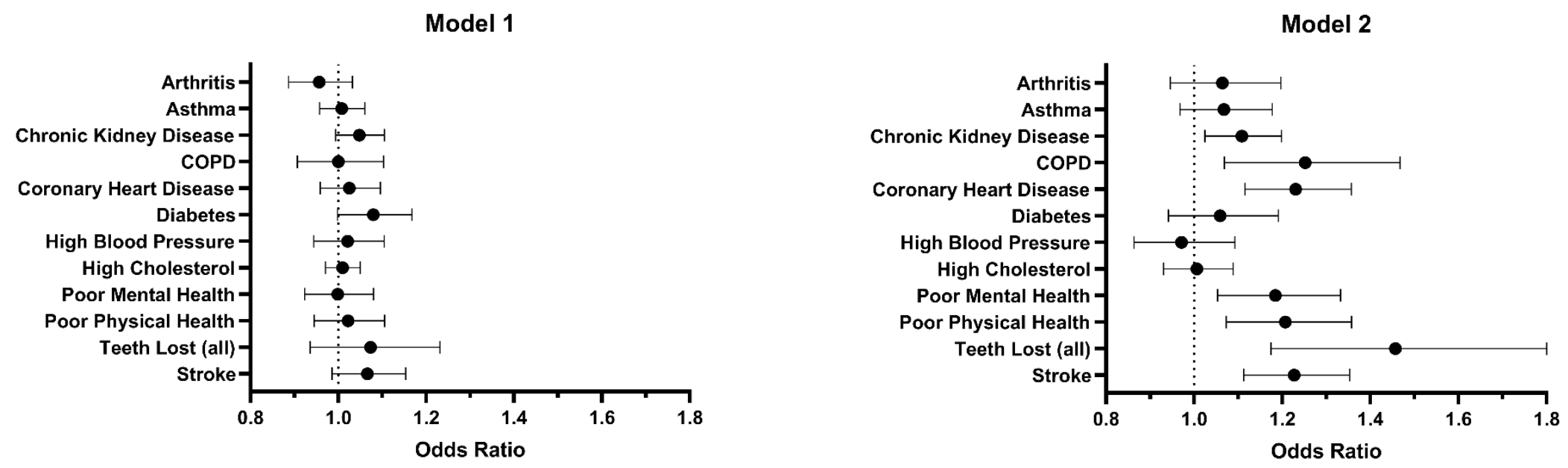

Model 3

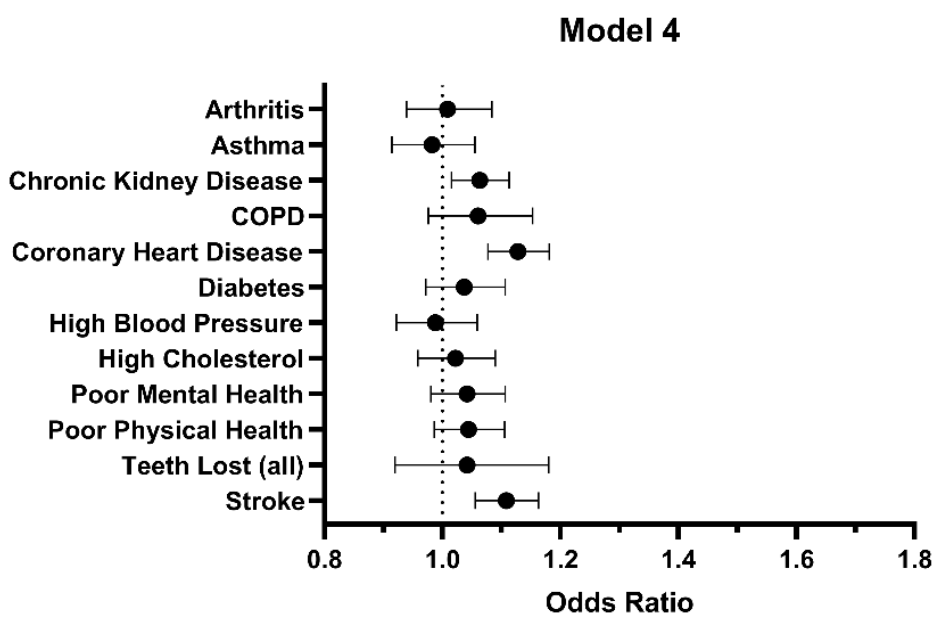

Figure 1. Odds ratios $( \pm 95 \%$ confidence interval) generated from hierarchical beta regression results using the logit link (18). Odds ratios are multipliers describing the impact of a $\$ 1$ billion increase in performing arts revenue on the $\%$ prevalence of each Health Outcome. 